Document downloaded from:

http://hdl.handle.net/10251/61519

This paper must be cited as:

Pascual Seva, N.; San Bautista Primo, A.; López Galarza, SV.; Maroto Borrego, JV.; Pascual España, B. (2015). Response of nutsedge (Cyperus esculentus L. var sativus Boeck.)

tuber production to drip irrigation based on volumetric soil water content. Irrigation Science. 33(1):31-42.

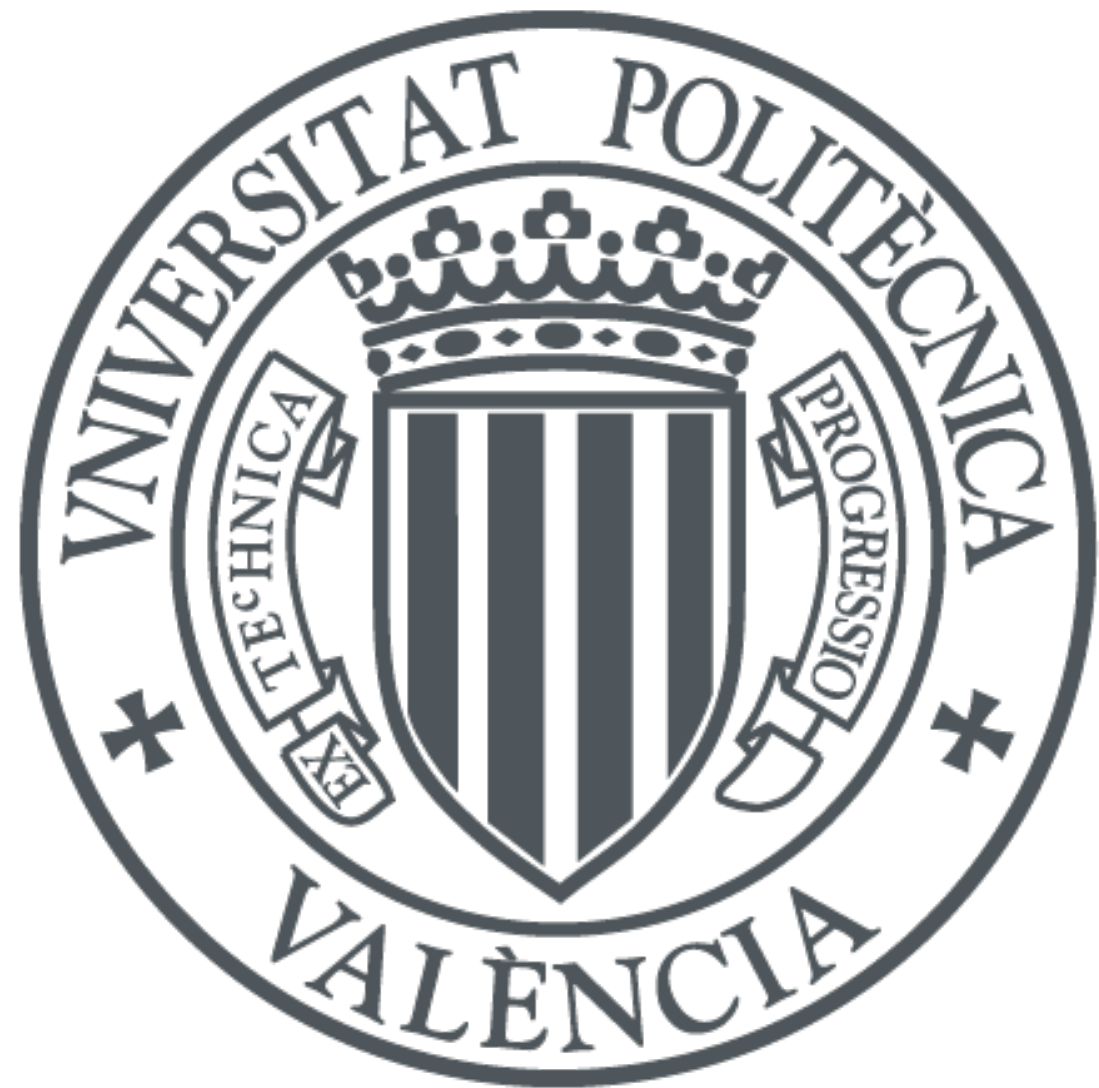

The final publication is available at

http://dx.doi.org/10.1007/s00271-014-0446-0

Copyright Springer Verlag (Germany)

Additional Information

The final publication is available at Springer via http://dx.doi.org/10.1007/s00271-014-0446-0 


\title{
Response of Nutsedge (Cyperus esculentus L. var sativus Boeck.) tuber production to drip irrigation based on volumetric soil water content
}

Pascual-Seva N., San Bautista A., López-Galarza S., Maroto J.V. and Pascual B.

Department of Plant Production. Universitat Politècnica de València. Camino de Vera s/n, 46022 Valencia, Spain

Corresponding author:

Bernardo Pascual España

Telephone number: 0034-963877336

Fax number: 0034-963877339

E-mail: bpascual@prv.upv.es

\begin{abstract}
Cultivated nutsedge is a common crop in Valencia (Spain). The aim of this research, which was conducted over two consecutive years, was to compare the productive response of the nutsedge crop with drip irrigation and traditional furrow irrigation, calculating the yield and the irrigation water use efficiency (IWUE). The volumetric soil water content was monitored with capacitance probes. Four irrigation strategies were considered: three in drip irrigation [D70, D80, and D90 with refill points at $70 \%, 80 \%$, and $90 \%$ of the field capacity, respectively] and one in furrow irrigation (refill point at $60 \%$ field capacity); in the second year, the irrigation management was automated. On average, strategy D90 produced the highest yield and D70 the lowest, while the highest IWUE was obtained with D80 and the lowest with furrow irrigation. Considering the automation of irrigation management, strategy D90 led to the highest yield and to the highest IWUE.
\end{abstract}




\section{Introduction}

Nutsedge(Cyperus esculentus L. var. sativus) is also known as tiger nut or chufa. It is a common crop in the Valencia Region (Spain), where nutsedge tubers are used to produce a beverage called "horchata" or "horchata de chufas" (nutsedge milk). The milky aqueous extract has a pleasant flavour that brings to mind vanilla and almonds. This refreshing and wholesome beverage has recently become popular in other countries, such as France, the UK, the USA and Argentina. Recent studies have reported increasing interest in nutsedge cultivation, mostly for food technology and biodiesel production in Brazil, Cameroon, China, Egypt, Hungary, the Republic of Korea, Poland, Turkey and the USA (Pascual-Seva et al. 2009). Research on various aspects of nutsedge cultivation, like crop management techniques, cultivar selection and plant characterisation, is reviewed in Pascual et al. (1999), and studies on nutsedge nutrition and fertilisation have also been conducted (Pascual-Seva et al. 2009).

Traditionally, nutsedge has been furrow irrigated, although until recently no data on the volumes of water used for irrigation were available. In the region where nutsedge is grown, water is readily available and inexpensive, and the cost is calculated in terms of the farm surface area rather than the actual volume of water used. However, due to extended periods of drought and the shift of water usage from irrigation to environmental, industrial and municipal applications, use of irrigation water may soon become subject to regulation.

Molden et al. (2003) listed different strategies for improving water productivity values, including increasing the productivity per unit of water consumed (by improving water management, establishing better timing of supplies to reduce stress at critical stages of crop growth, thus leading to higher yields) and lowering non-beneficial depletion (by reducing water flow to sinks with techniques that diminish irrecoverable deep percolation and surface runoff). Within this context, a line of research was initiated to identify the best practices for the management of the irrigation of the nutsedge crop. Pascual-Seva et al. (2013a, b) presented irrigation application efficiency (AE) and water distribution uniformity indices in furrow irrigation (FI), determined in the traditional nutsedge cultivation area, where flow delivered by open channel had been neither measured nor controlled. Likewise, irrigation was optimised by the development and validation of an empirical function estimating irrigation time as a function of flow discharge.

Water use efficiency (WUE) and irrigation water use efficiency (IWUE) are common indicators employed to assess the efficiency of the use of irrigation water in crop production (Bos 1980; Tolk and 
Howell 2003). WUE was defined by Viets (1962) as the weight of dry matter or marketable crop produced per unit volume of water used in evapotranspiration. The denominator in this ratio is difficult to determine with precision, particularly when the crop coefficient is unknown. However, for a specific region and to identify differences between irrigation methods and/or irrigation management, it can be substituted for the sum of the effective rainfall, the irrigation applied and the soil water depletion from the root zone during the growing season (Howell 2001). The IWUE is defined as the increase in yield under irrigated production compared to that under dryland production (Bos 1980), but this expression has also been used to relate the yield to the volume of irrigation water applied ( $I_{\text {applied }}$; Tolk and Howell 2003).

Using drip irrigation (DI) is one of the possible strategies for improving WUE and IWUE values. DI was first used in nutsedge cultivation in a previous experiment performed in 2006 on a research plot (Pascual-Seva et al. 2008). This experiment analysed the productive response of nutsedge and its corresponding IWUE to different irrigation strategies (IS). Irrigation scheduling was based on the depletion of the volumetric soil water content (VSWC), which was monitored continuously with capacitance probes, each irrigation event being initiated when the VSWC dropped to $65 \%, 77.5 \%$ or $90 \%$ of the field capacity (FC). In this study, it was stated that DI could be an alternative to traditional irrigation in nutsedge crops. Nevertheless, the $65 \%$ strategy resulted in a yield lower than that usually obtained by farmers, therefore, these IS needed to be adjusted.

The present study describes the response of nutsedge under DI compared to that grown under traditional FI. The growth of the whole plant was analysed, the yield and the water volumes used were determined, and both the WUE and the IWUE were calculated.

\section{Materials and methods}

The experiments were conducted over two consecutive years (2007 and 2008) in two adjacent commercial plots next to the campus of the Universitat Politècnica de València, Spain $\left(39^{\circ} 38^{`} \mathrm{~N}\right.$, $\left.0^{\circ} 22^{\prime} \mathrm{W}\right)$, within the main nutsedge producing area. These plots are representative of the plots in the region.

Variations in the VSWC were used to determine the in situ FC (Veihmeyer and Hendrickson 1931) and refill point (VSWC before each irrigation event), which determined the corresponding IS. Three different DI strategies were used (D70, D80 and D90) and irrigation began when the VSWC values at a soil depth of $0.10 \mathrm{~m}$ [Pascual-Seva et al. (2013b) stated that the maximum root density and water 
uptake by nutsedge plants occurred at a depth of $0.10 \mathrm{~m}$ ] dropped to $70 \%, 80 \%$ and $90 \%$ of the FC value. FI was scheduled so that each event began when the VSWC at a soil depth of $0.10 \mathrm{~m}$ reached approximately $60 \%$ of the FC. Each IS was replicated four times in a split plot design, each replication consisting in two ridges, which were surrounded by a similar ridge to eliminate border effects.

To avoid soil replant disorders resulting from serial nutsedge cropping, two different plots were used, both of which were next to the university experimental farm in order to facilitate the use of its DI installation, which is not common in the area. The two plots were owned by different farmers and, therefore, have different backgrounds. Tubers $\left(120 \mathrm{~kg}\right.$ tubers ha $\left.{ }^{-1}\right)$ were planted in ridges that were $0.20 \mathrm{~m}$ high, while the ridge top centre spacing was $0.60 \mathrm{~m}$. In both experiments, the furrow length was $80 \mathrm{~m}$, and the furrow slope was $0.1 \%$. The soils at the site are deep, with a coarse texture (Table 1 ), and are classified as Anthropic Torrifluvents according to the USDA Soil Taxonomy (Soil Survey Staff 2010). The analyses indicate that the soils have a slightly or moderately alkaline pH and are highly fertile (high organic matter content and high available phosphorous and potassium concentrations; Table 1). The soil was apparently uniform in depth all over the plot because of seedbed preparation, which entails two crossed passes with a rotary tiller, and the sieving of the soil when the tubers are harvested.

According to Papadakis's agro-climatic classification (MOPT 1992), the climate is subtropical Mediterranean (Su, Me) with hot, dry summers and an average annual rainfall of approximately $450 \mathrm{~mm}$, irregularly distributed throughout the year, with approximately $40 \%$ falling in autumn. Figure 1 shows the most significant climatological data about the growing seasons expressed as monthly values: temperature and precipitation registered in the experimental plot, and reference evapotranspiration (ETo) calculated by the Penman-Monteith formulation from the weather information obtained in an automated meteorological station located near the experimental plot.

The water for DI was pumped from a well $\left(\mathrm{EC}=1.6 \mathrm{dS} \mathrm{m} \mathrm{m}^{-1} ; \mathrm{SAR}_{\text {(adjusted) }}=2.9 ; \mathrm{pH}=7.4\right)$. The water for FI came from the Mestalla canal, which flows from the Turia river $\left(\mathrm{EC}=1.4 \mathrm{dS} \mathrm{m}^{-1}\right.$; $\mathrm{SAR}_{\text {(adjusted) }}=2.7 ; \mathrm{pH}=7.2$ ). Neither irrigation water source showed any restriction in terms of salinity for non-sensitive crops, such as nutsedge, or permeability (Ayers and Westcot 1994). There were, however, certain restrictions in water delivery in FI; in particular, growers could only irrigate for three straight days, followed by three days with no water available for irrigation.

In the DI plots, plants were irrigated by a single lateral line per plant row using a turbulent flow dripline (AZUDRIP Compact; Sistema Azud S.A., Murcia, Spain) with emitters $\left(2.2 \mathrm{~L} \mathrm{~h}^{-1}\right)$ spaced $0.25 \mathrm{~m}$ 
apart. The VSWC was continuously monitored with capacitance probes. One multi-depth capacitance probe (Cprobe; Agrilink Inc. Ltd., Adelaide, Australia) was installed inside a PVC access tube in a ridge of one repetition of each IS in the DI plots. These probes had sensors whose mid-points were placed at depths of $0.10,0.20$ and $0.30 \mathrm{~m}$ below the top of the ridge, and each was connected to a radio telemetry unit, which read the value of each sensor every $5 \mathrm{~min}$ and stored an average value every $15 \mathrm{~min}$, as reported in Hussein-Mounzer et al. (2008). The stored raw data were sent by radio through a relay station and then to a gateway connected to a computer for data analysis with the addVANTAGE software from ADCON telemetry GMbH (Vienna, Austria) (Vera et al. 2009). Before installation in the field, each sensor inside its PVC access tube was normalised by taking voltage readings while exposed to air (Va) and water $(\mathrm{Vw})$ at $\approx 22^{\circ} \mathrm{C}$ (Abrisqueta et al. 2012). The normalisation equation is defined as: scaled voltage $=(\mathrm{Va}-\mathrm{Vs}) /(\mathrm{Va}-\mathrm{Vw})$, where Vs is the voltage in the soil. Once the crop was established, the probes were calibrated in the field by the gravimetric method, readings being taken from each sensor (at different IS and depths) and non-disturbed soil samples in the same ridge the probes were in, at a maximum distance of $0.4 \mathrm{~m}$ from it. An undisturbed soil sample core (Ø $53 \mathrm{~mm}$; height $51 \mathrm{~mm})$ was taken every week, over a period of five weeks, with a soil sample ring kit (Eijkelkamp; Giesbeek, The Netherlands). Soil samples were dried at $105^{\circ} \mathrm{C}$ in a forced-air oven (Model 297; JP Selecta, Barcelona, Spain) to obtain the sample water content $\left(\mathrm{m}^{3} \mathrm{~m}^{-3}\right)$, which was compared with the corresponding scaled voltage value.

The irrigation scheduling was managed by maintaining the soil water content (scaled voltage) at a depth of $0.10 \mathrm{~m}$ between FC and the refill point. The amount applied in each irrigation event for the 2007 experiment was $14.7 \mathrm{~mm}$ on average (60 min), while in 2008 the installation management was automated, each event being stopped when the sum of the VSWC values at $0.10,0.20$ and $0.30 \mathrm{~m}$ reached the corresponding FC value. The rainfall and emitter flow rate were recorded using automatic tipping bucket gauges connected to the radio telemetry unit.

In FI plots, the flow of water was continuously gauged by a sensor (ISCO 2150 area velocity flow module; Teledyne ISCO Inc., Lincoln, NE, USA). The discharge data were measured and stored at $15 \mathrm{~s}$ intervals. Each irrigation dose was determined by integrating the flow and the application time. The furrows were blocked at the ends and, therefore, there was no runoff. One capacitance sensor $\mathrm{ECH}_{2} \mathrm{O}$ EC5 in a ridge, with $\mathrm{ECH}_{2} \mathrm{O}$ Utility software (Decagon Devices Inc., Washington, USA), was placed at a depth of $0.10 \mathrm{~m}$ and connected to an Em50 data-logger (Decagon Devices Inc., Washington, USA) to 
monitor the VSWC, which was provided in $\mathrm{m}^{3} \mathrm{~m}^{-3}$ (factory calibration provides $\pm 3 \%$ accuracy for mineral soils) and therefore used directly. The irrigation was scheduled so that each event began when the VSWC at a soil depth of $0.10 \mathrm{~m}$ reached approximately $60 \%$ of the $\mathrm{FC}$, bearing in mind that water delivery was restricted to a three-day-on / three-day-off schedule.

Planting was performed on 23 [113 day of the year (DOY)] and 24 April (115 DOY) in 2007 and 2008, respectively. Planting and harvesting were performed by the same farmer and the same machinery, while the remaining cultivation tasks were performed by the corresponding farm owner. Standard cultivation practices were followed during the crop period, as described in Pascual et al. (1997). Nutrient management was in accordance with local practices. The basal dressing, applied the day before planting, consisted of $2 \mathrm{~kg} \mathrm{~m}^{-2}$ sheep manure (57.2\% Dw; 60.9\% o.m. Dw) and $90 \mathrm{~g} \mathrm{~m}^{-2}$ 15:15:15 (N: $\left.\mathrm{P}_{2} \mathrm{O}_{5}: \mathrm{K}_{2} \mathrm{O}\right)$. The top dressing in DI was based on Hoagland's No. 2 nutrient solution (Maynard and Hochmuth 1997) [EC: $2.31 \mathrm{dS} \mathrm{m}^{-1}$; $\mathrm{pH}$ adjusted to 6.1 ; macronutrient concentrations (all in $\mathrm{mM}$ ): $\mathrm{NO}_{3}^{-}, 14.0 ; \mathrm{H}_{2} \mathrm{PO}_{4}^{-}, 1.0$; $\mathrm{SO}_{4}^{2-}, 2.45 ; \mathrm{K}^{+}, 6.0 ; \mathrm{Ca}^{2+}, 4.0 ; \mathrm{Mg}^{2+}, 2.0$; micronutrient concentrations (all in $\mu \mathrm{M}$ ): $\mathrm{Fe}^{2+}, 15 ; \mathrm{Mn}^{2+}, 10$; $\left.\mathrm{Zn}^{2+}, 5 ; \mathrm{B}^{3+}, 30 ; \mathrm{Cu}^{2+}, 0.75 ; \mathrm{Mo}^{6+}, 0.5\right]$ applied, up to $3.12 \mathrm{~g} \mathrm{~m}^{-2}$ of $\mathrm{N}$, during the first two weeks of July through the irrigation system. In FI, the top dressing consisted of $3.12 \mathrm{~g} \mathrm{~m}^{-2} \mathrm{~N}$ in $\mathrm{NO}_{3} \mathrm{~K}$ form and was applied with the 8 July 2007 and 16 July 2008 irrigation events.

Plants within $1 \mathrm{~m}$ of the plant row were sampled from each experimental plot regularly for six months. Plants were divided into three parts and analysed separately: (i) shoots with all of their leaves (hereinafter referred to as leaves); (ii) roots and rhizomes as a whole, given the difficulty of separating them (hereinafter referred to as roots); and (iii) tubers. Plant height was measured and the shoots and tubers were counted at each sampling (data not shown). After washing, each sampled plant part (leaves, roots or tubers) was dried at $65^{\circ} \mathrm{C}$ in a forced-air oven until constant weight to obtain dry weights and tuber dry-matter content. The harvest index (HI) was calculated for each sampling as the ratio of tuber yield to total biomass, including root system, on a dry matter basis ( $\mathrm{g} \mathrm{g}^{-1}$; Van der Veeken and Lommen 2009).

In the 2007 experiment, straw-burning took place on 20 November 2007; the tubers were harvested and washed on 16 and 17 January 2008, respectively; in the 2008 experiment, these dates were 7 November 2008, and 27 and 28 January 2009, respectively. As the crop coefficient $\left(\mathrm{K}_{\mathrm{c}}\right)$ of nutsedge is unknown, the WUE was calculated as the relationship between marketable yield (fresh tuber) and total water input (irrigation + rainfall; Ko and Piccinni 2009); the IWUE was calculated as the relationship 
between marketable yield (fresh tuber) and $I_{\text {applied }}$ (Cabello et al. 2009). For each event, AE was estimated as the ratio between the amount of water that could be stored in the root zone and the $I_{\text {applied }}$.

The data were analysed by an analysis of variance using Statgraphics 5.1 plus (Statistical Graphics Corporation 2005).

\section{Results and discussions}

Table 2 shows the different linear calibration equations for the diverse multi-depth capacitance probes, which showed high correlation coefficients (r: 0.87-0.99) and significance level $(P \leq 0.01)$. These correlations can be considered appropriate, even more taking into account the possible errors associated with obtaining and processing the samples (Quemada et al. 2010).In general, the relationship between VSWC and the corresponding scaled voltage is not linear (Bell et al. 1987; Vera et al. 2009), yet, as occurred in this study, the calibration curves may be regarded as linear over the relatively restricted range of soil moisture changes normally experienced for a given soil (Bell et al. 1987). As was expected given the apparent uniformity of the soil, when comparing the calibration equation slopes, there were no significant differences $(P \leq 0.05)$ for the different sensor depths or for the different IS, and thus a single calibration could be reported for the combined depths and IS. Nevertheless, the low correlation coefficients obtained for each year, including the different IS, made the use of separate equations the most advisable option. The FC and refill point values for each depth, IS and experiment are shown in Table 3.

Figure 2 shows the VSWC throughout the growth period for all of the IS and for both years, as well as the daily rainfall. In DI for both growing seasons, VSWC at a depth of $0.30 \mathrm{~m}$ was higher than at shallower depths and it increased with increasing refill point, with lower values in 2008 than in 2007 due to the automation of irrigation management. On 14 July 2007 (196 DOY), the D90 strategy showed an increase in VSWC (especially at depths of 0.2 and $0.3 \mathrm{~m}$ ) due to a solenoid valve breakage. Although in FI water delivery was restricted to the three-day-on / three-day-off schedule, the refill point was close to the scheduled irrigation programme.

Seasonal rainfall was higher in 2007 (Fig. 1), although the second part of spring 2008 was notably wetter, which delayed the start of irrigation by one month (Fig. 2) and reduced the number of irrigation events and, consequently, the $I_{\text {applied }}$. Considering ETo from planting to the last irrigation event in each year [12 Oct (DOY 285) in 2007 and 19 September (DOY 263) in 2008; water requirement considered as ETo instead of ETc, since $\mathrm{K}_{\mathrm{c}}$ of nutsedge is unknown], it can be stated that larger amounts 
of water were required in $2007(\mathrm{ETo}=722 \mathrm{~mm})$ than in $2008(\mathrm{ETo}=630 \mathrm{~mm})$. In FI plots, there were 10 irrigation events in 2007 and 8 events in 2008, and the $I_{\text {applied }}$ was $1027 \mathrm{~mm}$ in 2007 and $800 \mathrm{~mm}$ in 2008, which represented $142 \%$ and $127 \%$ of the ETo, respectively. In DI plots, there were 29, 36 and 60 irrigation events for D70, D80 and D90, respectively, in 2007, and 25, 29 and 44 events in 2008. The corresponding $I_{\text {applied }}$ were 384,504 and $763 \mathrm{~mm}$ in 2007, and 313, 375 and $450 \mathrm{~mm}$ in 2008, which represented $53.2 \%, 69.8 \%$ and $105.7 \%$ of ETo, respectively, in 2007 and $49.7 \%, 59.6 \%$ and $71.4 \%$ in 2008. The smaller $I_{\text {applied }}$ in 2008 is mainly related to the shortening of the irrigation period due to the spring rains, and also to the lower ETo. Percentages obtained in 2008 show a better adjustment of the $I_{\text {applied }}$ to the water requirements (ETo). The differences observed between the IS can be explained in part by the different AE obtained in each IS, with values of 75\%, 64\%, 27\% and $19.5 \%$ for D70, D80, D90 and FI, respectively, in 2007; 83\%, 56\%, 53\% and 20\% for D70, D80, D90 and FI, respectively, in 2008. Most of these AE values are very low, but the shallowness of the roots $(\approx 0.20 \mathrm{~m})$ is a factor that should be noted and taken into account. The improvement in AE achieved for DI in 2008 compared to 2007 was due to the reduction in deep percolation by automating the irrigation management in 2008 , thereby reducing the application time (on average $14.3 \%$, from $56.6 \mathrm{~min}$ to $48.5 \mathrm{~min}$ ) and consequently the $I_{\text {applied }}$ (on average from $13.85 \mathrm{~L} \mathrm{~m}^{-2}$ to $11.87 \mathrm{~L} \mathrm{~m}^{-2}$ ) in each event. AE obtained in FI were lower than those obtained in a parallel study performed with furrow-irrigated nutsedge crop, $31 \%$ and $26 \%$ in 2007 and 2008, respectively (Pascual-Seva et al. 2013b), and they could clearly be improved as the authors stated in that study. In DI, AE could probably also be improved, by shortening the irrigation time in each event, which could be achieved by considering other irrigation stops, such as scheduling it based on the $0.2 \mathrm{~m}$ depth sensor or on the sum of the depths of 0.1 and $0.2 \mathrm{~m}$.

Soil evaporation was probably lower in DI than in FI. This was in agreement with the findings of Bernstein and Francois (1973) in a study to compare drip, furrow and sprinkler irrigation (bell pepper being chosen as the experimental plant) which indicated that the saving in water occurred while the crop was young. Results also showed that for mature crops water requirements were similar for the three methods of irrigation, and water saving by DI would depend largely on the inefficiency of the method it replaces. In DI the percentage of wetted surface is clearly lower than that in furrow irrigation, and so the soil evaporation both in the initial stage and in the crop development stage is lower. When the topsoil dries out, less water is available for evaporation, and evaporation from the exposed soil decreases in proportion to the amount of water remaining in the surface soil (Allen et al. 1998). Evaporation occurs 
predominantly from the exposed soil fraction, i.e., the fraction of the soil not covered by vegetation and that is wetted by irrigation or precipitation, which at the beginning of the crop development stage in the FI plots is practically the whole surface, while in DI plots it will not be higher than $25 \%$. In cotton, during the development period, DI with a fraction of the field surface wetted by the irrigation of 0.3 can reduce the value of $\mathrm{Kc}$ (soil evaporation coefficient + basal crop coefficient) by $11 \%$, in comparison to that obtained in furrow irrigation, and by $36 \%$ in the soil evaporation coefficient (Allen et al. 1998).

The plant height increased up to $105 \mathrm{~cm}$ in 2007 and $90 \mathrm{~cm}$ in 2008, following a seasonal sigmoid curve (data not shown) in agreement with Pascual-Seva et al. (2013a); no differences were observed among IS. Plant biomass increased during the cultivation phases to $2.3 \mathrm{~kg} \mathrm{~m}^{-2}$ in 2007 and 1.92 $\mathrm{kg} \mathrm{m}^{-2}$ in 2008 (Fig. 3a); these values corresponded to the D90 strategy, with leaves, tubers and roots representing $39.2 \%, 59.0 \%$ and $1.8 \%$ of this amount, respectively, in 2007 and $46.2 \%, 51.6 \%$ and $2.2 \%$, respectively, in 2008 (Fig. 4). With DI, there were only three irrigation strategies used for each growing season; thus, there were not enough values to obtain a consistent mathematical function relating the biomass to the $I_{\text {applied }}$. Nevertheless, a positive linear increase in biomass ( $\mathrm{y}=$ biomass in $\mathrm{g} \mathrm{m}^{-2}$ ) with $I_{\text {applied }}$ $\left(\mathrm{x}=I_{\text {applied }}\right.$ in $\left.\mathrm{mm}\right)$ was observed for each year $[\mathrm{y}=1679.1+0.8407 \mathrm{x}(\mathrm{r}=0.87 ; P \leq 0.01)$ for 2007; $\mathrm{y}=1799.4+0.2503 \mathrm{x}(\mathrm{r}=0.95 ; P \leq 0.01)$ for 2008$]$. When considering both years as a whole, a quadratic trend was observed, since the AE for D90 in 2007 was very low, and consequently the larger $I_{\text {applied }}$ did not lead to biomass production, but this model was not statistically significant $(P \leq 0.05)$ and the best adjustment corresponded to a linear relationship $[\mathrm{y}=1551+1.0047 \mathrm{x}(\mathrm{r}=0.80 ; P \leq 0.01)]$.

The aboveground biomass accounted for most of the plant biomass obtained with the four treatments during the first half of the growing period. By the middle of August (approximately 225 DOY), the tuber biomass made up most of the plant biomass due to processes of translocation to the tubers and leaf senescence (Fig. 3 and Fig. 4). From the end of July (210 DOY), FI led to the highest HI values (Fig. 3d), initially due to the higher tuber yield and later to the lower aboveground biomass.

The HI ranged from 0.46 to 0.66 at the time of commercial harvest, values being $0.66,0.52,0.59$ and 0.59 for FI, D70, D80 and D90, respectively, in 2007 and 0.56, 0.46, 0.49 and 0.51, in 2008. These 2008 values are lower than normal (Pascual-Seva et al. 2013a), most likely because the tuber biomass did not increase in the last phase of the cultivation cycle; the value for D70 is particularly low, and could be related with a shortage of irrigation water. The average values for 2007 are similar to or slightly lower than those reported for potato (0.61-0.87; Condori et al. 2008; Mushagalusa et al. 2008; Van der Veeken 
and Lommen 2009), which is also grown for tuber production. Nutsedge, similarly to potato, is a highly productive species in which the tubers contain the largest portion of accumulated biomass. The HI values obtained with the four irrigation strategies did not differ significantly, which agrees with the results reported for many other crops, as marketable yield is often directly related to plant biomass (Clemmens and Molden 2007).

Values of yield, HI, average tuber weight, small tuber percentage, tuber dry matter content, $I_{\text {applied, }}$ IWUE and WUE corresponding to the moment of commercial harvest for the different irrigation strategies are given in Table 4.

Both growing season (GS) and IS significantly affected $(P \leq 0.01)$ tuber yield. Differences for GS (on average $2.31 \mathrm{~kg} \mathrm{~m}^{-2}$ in 2007 and $1.74 \mathrm{~kg} \mathrm{~m}^{-2}$ in 2008) could be expected because yield, besides irrigation, depends on other factors such as climatic conditions, planting date, soil characteristics, fertilisation, pest and disease incidence, etc. It has been reported that obtaining different nutsedge yields for different years in any given plot is common (Pascual-Seva et al. 2013a), and in this study crop management was carried out by different farmers on two plots with different backgrounds. The average yield obtained with D80 $\left(2.13 \mathrm{~kg} \mathrm{~m}^{-2}\right)$ is considered to be a good yield in growers' fields; thus, the average yield obtained with D90 $\left(2.58 \mathrm{~kg} \mathrm{~m}^{-2}\right)$ can be considered very high. Both strategies led to greater yields than D70 and FI (without any differences between them). This is most likely due to the fact that DI provides the crop with a more regular soil moisture profile during the growing season (Fig. 2). In agreement with Bresler (1977), the maintenance of continuously high water potential (and then VSWC) during the growing season is an important and advantageous characteristic of DI, and crop yield-irrigation relationships depend on both the average of the soil-water regime indexes and the time deviations from them. Generally, surface irrigation causes large time fluctuations in the soil-water regime (Bresler 1977). In this study, the VSWC fluctuation was larger in FI than in DI, both lower refill point values $(60 \%$ of FC for $\mathrm{FI}$, and $70 \%, 80 \%$ and $90 \%$ of $\mathrm{FC}$, for the different strategies of DI) and higher VSWC values being registered in FI after each irrigation event, indeed considerably higher than FC (Fig. 2). The low yield obtained in D70 was a consequence of a water shortage more than VSWC fluctuations.

In DI, when each GS is analysed separately, yield $\left(\mathrm{y}=\right.$ yield in $\left.\mathrm{kg} \mathrm{m}^{-2}\right)$ increased linearly with $I_{\text {applied }}\left(\mathrm{x}=I_{\text {applied }}\right.$ in $\left.\mathrm{mm}\right)[\mathrm{y}=1.1151+0.2226 \mathrm{x}(\mathrm{r}=0.93 ; P \leq 0.01)$ in $2007 ; \mathrm{y}=-0.8155+0.0071 \mathrm{x}$ $(\mathrm{r}=0.96 ; P \leq 0.01)$ in 2008; Fig. 5]. These linear relationships agree with those reported by Shock et al. (1998) for potato (considering the sum of irrigation and precipitation). Tolk and Howell (2003) reported 
both linear and curvilinear relationships. Howell et al. (1995) stated, on corn, a linear relationship for one year and a quadratic relationship for the same study repeated the following year. Non-linear relationships are explainable if the HI varies with the water deficits (Tolk and Howell, 2003). In our experiment, HI did not differ between IS, and therefore when each year is analysed separately the yield- $I_{\text {applied }}$ relationships are linear. However, $\mathrm{HI}$ is statistically affected $(P \leq 0.05)$ by the GS, thus when considering data from both GS together, the relationship is curvilinear $\left[y=-1.9183+0.0138 x+1 \cdot 10^{-5} x^{2}\left(R^{2}=93.45 \% ; P \leq 0.01\right)\right.$; Fig. 5]. It is likely that a considerable amount of $I_{\text {applied }}$ is not consumed by ET and that at maximum irrigation applications (especially in D90 in 2007) a fraction of the $I_{\text {applied }}$ does not lead to yield increases, as reported by Tolk and Howell (2003).

The GS affected (Table 4) the average tuber weight $(P \leq 0.01)$, the small tuber percentage $(P \leq 0.01)$ and the tuber dry matter content $(P \leq 0.01)$, which resulted in the greatest average tuber weight and tuber dry matter content, and the lowest small tuber percentage, thereby indicating a better quality of the tubers in 2007 , besides the greatest yield obtained, as mentioned above. The significant $(P \leq 0.05)$ GS*IS interaction shows that average tuber weight in FI was lower $(P \leq 0.01)$ than in all DI strategies in 2008 , but it was only lower $(P \leq 0.01)$ than in D90 in 2007. Tuber dry matter content depends on the degree of tuber maturity and on tuber water loss before harvest, which in turn depends on the VSWC. Although the capacitance sensors were withdrawn before burning, small differences are foreseeable between VSWC in the period before harvest due to small variations between rainfalls registered in this period in both GS. Hence, differences $(P \leq 0.01)$ in tuber dry matter content were likely to be related to the higher degree of maturation of the 2007 tubers at harvesting. In fact, higher percentages of small tubers $(\leq 6 \mathrm{~mm})$ were obtained in $2008(7.5 \%)$ than in $2007(4.7 \%)$, which is related to a delay in tuber growth and maturation. Given the existence of a positive linear increment in "horchata" production yield with tuber dry matter content, this parameter should be considered in nutsedge tuber trade relations, as the small tuber percentage is currently considered.

Both GS $(P \leq 0.05)$ and IS $(P \leq 0.01)$ influenced IWUE (Table 4), with the highest values in 2007 and D80. The interaction GS*IS was also significant $(P \leq 0.01)$, leading to higher values of D70 and D80 (4.92 and $4.77 \mathrm{~kg} \mathrm{~m}^{-3}$, respectively) than D90 $\left(3.68 \mathrm{~kg} \mathrm{~m}^{-3}\right.$ ) in 2007 , while the opposite behaviour was observed in 2008, with the highest IWUE obtained with D90 $\left(5.26 \mathrm{~kg} \mathrm{~m}^{-3}\right)$, which differed significantly from D70 $\left(4.45 \mathrm{~kg} \mathrm{~m}^{-3}\right)$ but not from D80 $\left(4.96 \mathrm{~kg} \mathrm{~m}^{-3}\right)$. These results show how the larger yield obtained in 2007 for D90 did not compensate the larger $I_{\text {applied }}$ due to the low AE. In 2008, with the automation of 
irrigation, AE was improved and the larger $I_{\text {applied }}$ for D90, compared to D70 and D80, was compensated with a greater yield. The range of average IWUE values for DI strategies was narrow $\left(4.47-4.86 \mathrm{~kg} \mathrm{~m}^{-3}\right)$ when both GS are considered jointly; differences in IWUE between their lowest and highest average values for DI were $8.7 \%$. However, when each year is analysed separately, these differences increased by up to $33.7 \%$ in 2007 and $18.2 \%$ in 2008.

For DI strategies, IWUE $\left(\mathrm{y}=\mathrm{IWUE}\right.$ in $\left.\mathrm{kg} \mathrm{m}^{-3}\right)$ decreased with increasing $I_{\text {applied }}\left(\mathrm{x}=I_{\text {applied }}\right.$ in $\mathrm{mm})$ in $2007[\mathrm{y}=6.3386-0.0034 \mathrm{x}(\mathrm{r}=-0.93 ; P \leq 0.01)]$, when low AE were obtained, especially for D90, but it increased with $I_{\text {applied }}$ in $2008[\mathrm{y}=2.6760+0.0058 \mathrm{x}(\mathrm{r}=0.72 ; P \leq 0.01)]$ (Fig. 5), when irrigation management was automated. Considering data from both years as a whole, the best adjustment corresponded to a quadratic increase in IWUE in relation to $I_{\text {applied }}\left[\mathrm{y}=1.103+0.0016 \mathrm{x}-2 \cdot 10^{5} \mathrm{x}^{2}\right.$ $\left.\left(\mathrm{R}^{2}=0.72 ; P \leq 0.01\right)\right]$. This agrees with results reported for potato by both Yuan et al. (2003) and Shahnazari et al. (2007). Howell et al. (1990) indicated that maximum WUE tends to occur at maximum ET, and maximum IWUE usually occurs at an ET that is generally less than the maximum ET, thereby suggesting that irrigating to achieve the maximum yield would not be the most efficient use of irrigation water (Tolk and Howell 2003). In the present study, D90 in 2007 presented the highest yield but the lowest IWUE for DI, due to the larger $I_{\text {applied }}$, as a consequence of the low AE. The maximum IWUE was obtained for D90 in 2008, when the irrigation management was automated, and then $I_{\text {applied }}$ was closer to water requirements, resulting in higher AE than in 2007.

The IS and the GS*IS interaction affected $(P \leq 0.01)$ WUE (Table 4$)$, with no differences between D80 (2.40 $\left.\mathrm{kg} \mathrm{m}^{-3}\right)$ and D90 (2.22 $\left.\mathrm{kg} \mathrm{m}^{-3}\right)$ values in 2007, whereas in $2008 \mathrm{D} 80$ resulted in lower values $\left(2.29 \mathrm{~kg} \mathrm{~m}^{-3}\right)$ than D90 $\left(2.67 \mathrm{~kg} \mathrm{~m}^{-3}\right)$, when, as mentioned above, irrigation management was automated.

The results show that IWUE and WUE behave differently with different strategies. If it is considered that in the context of irrigation IWUE is economically more relevant than WUE (Farré and Faci, 2009), the value of which (calculated as the relationship between yield and total water input, i.e. irrigation + rainfall) depends on the variation in the amounts and distribution of seasonal rainfall, then IWUE appears to be a more useful indicator of water use than WUE.

The current cost of irrigation water is calculated in terms of the farm surface area, $60 €$ ha $^{-1}$ year $^{-}$ ${ }^{1}$, which, taking into account the average $I_{\text {applied }}$ in FI, means that the approximate water cost would be $0.005 € \mathrm{~m}^{-3}$. Considering the difference between the average IWUE in DI $\left(4.67 \mathrm{~kg} \mathrm{~m}^{-3}\right)$ and in FI $(1.89 \mathrm{~kg}$ 
$\left.\mathrm{m}^{-3}\right)$ and the stable average tuber price in recent years $\left(0.60 € \mathrm{~kg}^{-1}\right)$, in the present study conditions the application of DI would suppose an average increment in the gross revenue of $2674 € \mathrm{ha}^{-1}$ or $1.7 € \mathrm{~m}^{-3}$. Considering an average value of the energy requirement for DI $\left(0.105 \mathrm{kWh} \mathrm{m}^{-3}\right.$; Solomon, 2007) and for pumping water in the cultivation area $\left(0.4 \mathrm{kWh} \mathrm{m}^{-3}\right.$; Corominas, 2009) as well as the energy price $(0.1305$ $€ \mathrm{KWh}^{-1}$ with no time restrictions; MINETUR, 2014), the average energy costs of this DI system could be considered as $0.066 € \mathrm{~m}^{-3}$. Taking this into account as well as the increase in revenue, the utilisation of DI would suppose an average gross margin increment of $2368 € \mathrm{ha}^{-1}$ or $1.63 € \mathrm{~m}^{-3}$. The current average cost of the DI systems in Valencia (Spain) is around $2500 €$ ha $^{-1}$ (which coincides with the cost shown by Solomon, 2007). Then, it can be stated that DI is an interesting alternative to the traditional irrigation used with nutsedge crops.

\section{Conclusions}

With the irrigation management used in this study (both in drip and furrow irrigation), drip irrigation led to both higher yields and higher IWUE than those obtained with furrow irrigation. When the irrigation has been scheduled on the basis of the VSWC instead being based on time, considerably less deep percolation occurred and thus important water savings were achieved.

The objective of researchers and growers is to increase either yields or profits. When water availability is not the limiting factor, irrigating to achieve a maximum yield (although decreasing IWUE) may be the most profitable option. If, in the future, water were the limiting factor, irrigating to achieve maximum IWUE might be the best option. In this sense, when irrigation management was automated, the least restrictive strategy (D90) led not only to the highest yield but also to the highest IWUE.

Future research should aim to determine the $K_{c}$ of nutsedge, including the separation of evaporation and transpiration, which would facilitate an evapotranspiration-based irrigation management system in addition to improvements in irrigation water use efficiency.

\section{Acknowledgements}

This study was funded by the Regulatory Council of Denomination of Origin Chufa of Valencia of Spain 


\section{References}

Abrisqueta I, Vera J, Tapia LM, Abrisqueta JM, Ruiz-Sánchez MC (2012) Soil water content criteria for peach trees water stress detection during the postharvest period. Agric Water Manage 104:62-67

Allen RG, Pereira LS, Raes D, Smith M (1998) Crop evapotranspiration. Guidelines for computing crop water requirements. FAO, Rome, Italy

Ayers RS, Westcot DW (1994) Water quality for agriculture. FAO Irrigation and Drainage, 29 Rev1. FAO, Roma, Italy

Bell JP, Dean TJ, Hodnett MG (1987) Soil moisture measurements by an improved capacitance technique, part II. Field techniques, evaluation and calibration. J Hydrol 93:79-90

Bernstein L, Francois LE (1973) Comparisons of drip, furrow, and sprinkler irrigation. Soil Sci 115:73-86

Bos MG (1980) Irrigation efficiencies at crop production level. ICID Bull 29:18-25

Cabello MJ, Castellanos MT, Romojaro F, Martínez-Madrid C, Ribas F (2009) Yield and quality melon grown under different irrigation and nitrogen rates. Agric Water Manage 96:886-874

Bresler E (1977) Trickle-drip irrigation: principles and application to soil-water management. Adv Agorn 29:343-393

Clemmens AJ, Molden DJ (2007) Water uses and productivity of irrigation systems. Irrig Sci 25:247-261

Condori B, Mamani P, Botello R, Patiño F, Devaux A, Ledent JF (2008) Agrophysiological characterisation and parameterisation of Andean tubers: Potato (Solanum sp.), oca (Oxalis tuberosa), isaño (Tropaeolum tuberosum) and papalisa (Ullucus tuberosus). Europ J Agron 28:526-540

Corominas J (2009) Agua y energía en el riego, en la época de la sostenibilidad. Ingeniería del agua $17: 219-233$

Farré I, Faci JM (2009) Deficit irrigation in maize for reducing agricultural water use in a Mediterranean environment. Agric Water Manage 96:383-394

Howell TA (2001) Enhancing water use efficiency in irrigated agriculture. Agron J 93:281-289

Howell TA, Cuenca RH, Solomon KH (1990) Crop yield response. In: GJ Hoffman, TA Howell, KH Solomon (eds), Management of farm irrigation systems. ASAE, St Joseph, MI, USA, pp:93-122

Howell TA, Yazar A, Schneider AD, Dusek DA, Copeland KS (1995) Yield and water use efficiency of corn in response to LEPA irrigation. Trans ASAE 36:1737-1747

Hussein-Mounzer O, Mendoza-Hernández, JR, Abrisqueta-Villena I, Tapia-Vargas L, Abrisqueta-García JM, Vera-Muñoz J, Ruiz-Sánchez MC (2008) Soil water content measured by FDR probes and thresholds for drip irrigation management in peach trees. Agric Téc Méx 34:313-322

Ko J, Piccinni G (2009) Corn yield responses under crop evapotranspiration-based irrigation management. Agric Water Manage 96:799-808

Maynard DN, Hochmuth GJ (1997) Knott's handbook for vegetable growers. John Wiley \& Sons Inc., NY, USA.

MINETUR [Spanish Ministry of Industry, Energy and Tourism] (2014) Peajes y tarifas. Energía eléctrica. Ministerio de Industria, Energía y Turismo. http://www.minetur.gob.es/energia/electricidad/ Tarifas/Paginas/index.aspx. Accessed 3 August 2014

Molden D, Murray-Rust H, Sakthivadivel R, Makin I (2003) A water-productivity framework for understanding and action. In: JW Kjine, R Barker, D Molden (eds), Water productivity in agriculture. International Water Management Institute, Colombo, Sri Lanka, pp 1-18

MOPT [Spanish Ministry of Public Works and Transport] (1992) Guía para la elaboración de estudios del medio físico. Ministerio de Obras Públicas y Transporte, Madrid, Spain

Mushagalusa GN, Ledent JF, Draye X (2008) Shoot and root competition in potato/maize intercropping: Effects on growth and yield. Environ Exper Bot 64:180-188 
Pascual B, Maroto JV, López-Galarza S, Alagarda J, Castell-Zeising V (1997) El cultivo de la chufa (Cyperus esculentus L. var. sativus Boeck.). Estudios realizados. Generalitat Valenciana, Conselleria de Agricultura, Pesca y Alimentación, Valencia, Spain

Pascual B, Maroto JV, López-Galarza S, San Bautista A, Alagarda J (1999) Chufa (Cyperus esculentus L. var. sativus Boeck): an unconventional crop. Studies related to applications and cultivation. Econ Bot 54:439-448

Pascual-Seva N, San Bautista A., López-Galarza S, Alagarda J, Maroto JV, Pascual B (2008) Respuesta productiva de la chufa (Cyperus esculentus L. var. sativus Boeck.) en riego localizado. Actas de Horticultura 50:170-175

Pascual-Seva N, Pascual, B, San Bautista A, López-Galarza S, Maroto JV (2009) Growth and nutrient absorption in chufa (Cyperus esculentus L. var. sativus Boeck.) in soilless culture. J. Hort. Sci. Biot 84:393-398

Pascual-Seva N, San Bautista A, López-Galarza S, Maroto JV, Pascual B (2013a) Furrow-irrigated chufa crops in Valencia (Spain). I: Productive response to two irrigation strategies. Span J Agric Res 11:258267

Pascual-Seva N, San Bautista A, López-Galarza S, Maroto JV, Pascual B (2013b) Furrow-irrigated chufa crops in Valencia (Spain). II: Performance analysis and optimization. Span J Agric Res 11: 268-278

Quemada M, Gabriel JL, Lizaso J (2010) Calibration of capacitance probes: laboratory versus field Procedures. In: IC Paltineanu, J Vera (eds), Transactions. The third international symposium on soil water measurement using capacitance, impedance and TDT. CEBAS-CSIC, PALTIN International Inc, Murcia, Spain, pp: 2.2:1-14

Shahnazari A, Liu F, Andersen MN, Jacobsen SE, Jensen CR (2007) Effects of partial root-zone drying on yield, tuber size and water use efficiency in potato under field conditions. Field Crops Res 100:117124

Shock CC, Feibert EBG, Saunders LD (1998) Potato yield and quality response to deficit irrigation. HortScience 33:655-659

Soil Survey Staff (2010) Keys to Soil Taxonomy, 11th ed. USDA-Natural Resources Conservation Service, Washington DC, USA

Statistical Graphics Corporation (2005) Statgraphics Plus for Windows 5.1. Statistical Graphics, Rockville, Maryland, USA

Solomon KH, El-Gindy AM, Ibatullin SR (2007) Planing and system selection. In: GJ Hoffman, RG Evans, ME Jensen, DL Martin, RL Elliot (eds), Design and operation of farm irrigation systems. ASABE, St Joseph, MI, USA, pp:57-75

Tolk JA, Howell T (2003) Water use efficiencies of grain sorghum grown in three USA southern Great Plains soils. Agric Water Manage 59:97-111

Van der Veeken AJH, Loomen WJM (2009) How planting density affects number and yield of potato minitubers in a commercial glasshouse production system. Potato Res 52:105-119

Veihmeyer FJ, Hendrickson AH (1931) The moisture equivalent as a measure of the field capacity of soils. Soil Sci 32:181-193

Vera J, Mounzer O, Ruiz-Sánchez MC, Abrisqueta I, Tapia LM, Abrisqueta JM (2009) Soil water balance trial involving capacitance and neutron probe measurements. Agric Water Manage 96:905-911

Viets FG (1962) Fertilizers and the efficient use of wáter. Adv Agron 14:223-264

Yuan BZ, Nishiyama S, Kang Y (2003) Effects of different irrigation regimes on the growth and yield of drip-irrigated potato. Agric Water Manage 63:153-167 


\section{Tables}

Table 1 Textural and chemical characteristics of soils used in each experiment.

\begin{tabular}{lcc}
\hline & 2007 & 2008 \\
\hline Textural characteristics & & \\
Sand (\%) & 87.3 & 85.3 \\
Silt (\%) & 10.0 & 10.0 \\
Clay (\%) & 2.7 & 4.7 \\
Texture & Sand & Loamy sand \\
Chemical characteristics & & \\
pH & 8.4 & 7.8 \\
EC (1:5) (dS m ${ }^{-1}$ ) & 0.14 & 0.41 \\
Organic matter $(\%)$ & 1.7 & 2.2 \\
Total calcium carbonate (\%) & 33.9 & 5.3 \\
Active calcium carbonate (\%) & 5.3 & 3.5 \\
Phosphorous (sodium bicarbonate; $p$ pm) & 89 & 264 \\
Potassium (ammonium acetate; $p$ pm) & 264 & 382 \\
\hline
\end{tabular}

Table 2 Calibration equations ( $\mathrm{y}=$ volumetric soil water content in $\mathrm{m}^{3} \mathrm{~m}^{-3} ; \mathrm{x}=$ scaled voltage in $\% ; 5$ points used for each equation) for the diverse sensors in multi-depth capacitance probes used at depths of 0.10, 0.20 and $0.30 \mathrm{~m}$, corresponding to D70, D80 and D90 drip irrigation strategies in 2007 and 2008 experiments.

\begin{tabular}{|c|c|c|c|}
\hline & & 2007 & 2008 \\
\hline \multirow[t]{5}{*}{ D70 } & $0.10 \mathrm{~m}$ & $\begin{array}{c}\mathrm{y}=0.0065 \mathrm{x}+0.0141 \\
\mathrm{r}=0.94 * *\end{array}$ & $\begin{array}{c}\mathrm{y}=0.0028 \mathrm{x}+0.1351 \\
\mathrm{r}=0.95 * *\end{array}$ \\
\hline & $0.20 \mathrm{~m}$ & $y=0.0124 x-0.1807$ & $y=0.0050 x+0.0663$ \\
\hline & & $\mathrm{r}=0.89 * *$ & $\mathrm{r}=0.96 * *$ \\
\hline & $0.30 \mathrm{~m}$ & $y=0.0047 x+0.0387$ & $y=0.0049 x+0.0479$ \\
\hline & & $\mathrm{r}=0.95 * *$ & $\mathrm{r}=0.96 * *$ \\
\hline \multirow[t]{6}{*}{ D80 } & $0.10 \mathrm{~m}$ & $y=0.0055 x+0.0775$ & $y=0.0066 x+0.0166$ \\
\hline & & $\mathrm{r}=0.97 * *$ & $\mathrm{r}=0.93 * *$ \\
\hline & $0.20 \mathrm{~m}$ & $y=0.0151 x-0.1449$ & $y=0.0116 x-0.1429$ \\
\hline & & $\mathrm{r}=0.98 * *$ & $\mathrm{r}=0.99 * *$ \\
\hline & $0.30 \mathrm{~m}$ & $y=0.0194 x-0.2779$ & $y=0.0100 x-0.1309$ \\
\hline & & $\mathrm{r}=0.99 * *$ & $\mathrm{r}=0.94 * *$ \\
\hline \multirow[t]{6}{*}{ D90 } & $0.10 \mathrm{~m}$ & $y=0.0043 x+0.0690$ & $y=0.0155 x-0.1509$ \\
\hline & & $\mathrm{r}=0.98 * *$ & $\mathrm{r}=0.90 * *$ \\
\hline & $0.20 \mathrm{~m}$ & $y=0.0182 x-0.2682$ & $y=0.0074 x-0.0245$ \\
\hline & & $r=0.87 * *$ & $\mathrm{r}=0.99 * *$ \\
\hline & $0.30 \mathrm{~m}$ & $y=0.0105 x+0.0087$ & $y=0.0085 x-0.0918$ \\
\hline & & $\mathrm{r}=0.98 * *$ & $\mathrm{r}=0.95 * *$ \\
\hline
\end{tabular}

The irrigation strategies designated D70, D80, and D90 consisted in starting each irrigation event when the VSWC at a $0.10 \mathrm{~m}$ depth rose to 70,80 , and $90 \%$ of field capacity, respectively.

Table 3 Field capacity [FC; in Scaled Voltage (SV) and $\mathrm{m}^{3} \mathrm{~m}^{-3)}$ and refill point (RP; in \% of FC and $\mathrm{m}^{3}$ $\mathrm{m}^{-3}$ ) values for each drip irrigation strategy (D70, D80, D90) and for furrow irrigation (FI) in the growing seasons (2007 and 2008).

\begin{tabular}{|c|c|c|c|c|c|c|c|c|}
\hline & \multicolumn{4}{|c|}{2007} & \multicolumn{4}{|c|}{2008} \\
\hline & \multicolumn{2}{|c|}{$\mathrm{FC}$} & \multicolumn{2}{|c|}{$\mathrm{RP}$} & \multicolumn{2}{|c|}{$\mathrm{FC}$} & \multicolumn{2}{|c|}{ RP } \\
\hline & SV & $\mathrm{m}^{3} \mathrm{~m}^{-3}$ & $\%$ & $\mathrm{~m}^{3} \mathrm{~m}^{-3}$ & SV & $\mathrm{m}^{3} \mathrm{~m}^{-3}$ & $\%$ & $\mathrm{~m}^{3} \mathrm{~m}^{-3}$ \\
\hline D70 & 22.8 & 0.162 & 70 & 0.114 & 21.5 & 0.195 & 70 & 0.137 \\
\hline D80 & 23.2 & 0.205 & 80 & 0.164 & 23.3 & 0.170 & 80 & 0.136 \\
\hline D90 & 22.1 & 0.164 & 90 & 0.148 & 25.9 & 0.251 & 90 & 0.226 \\
\hline FI & - & 0.250 & 60 & 0.150 & - & 0.250 & 60 & 0.150 \\
\hline
\end{tabular}

The irrigation strategy designated D70, D80, and D90 consisted in starting each irrigation event when the VSWC at a $0.10 \mathrm{~m}$ depth rose to $70 \%, 80 \%$, and $90 \%$ of FC, respectively. 
Table 4 Influence of growing season (GS) and irrigation strategies (IS) on yield, average tuber weight (ATW), small tuber percentage (STP), tuber dry matter content (TDMC), harvest index (HI), irrigation water use efficiency (IWUE), and water use efficiency (WUE) of nutsedge under different irrigation strategies. Average values of 4 replicates. Irrigation water applied $\left(I_{\text {applied }}\right)$ in the different irrigation strategies.

\begin{tabular}{|c|c|c|c|c|c|c|c|c|}
\hline & $\begin{array}{c}\text { Yield } \\
\mathrm{Kg} \mathrm{m}^{-2}\end{array}$ & $\begin{array}{c}\text { ATW } \\
\text { g }\end{array}$ & $\begin{array}{c}\text { STP } \\
\%\end{array}$ & $\begin{array}{c}\text { TDMC } \\
\%\end{array}$ & $\begin{array}{c}\text { HI } \\
-\end{array}$ & $\begin{array}{c}I_{\text {applied }} \\
\mathrm{mm}\end{array}$ & $\begin{array}{l}\text { IWUE } \\
\mathrm{Kg} \mathrm{m}^{-3}\end{array}$ & $\begin{array}{c}\text { WUE } \\
\mathrm{Kg} \mathrm{m}^{-3}\end{array}$ \\
\hline \multicolumn{9}{|l|}{ Growing season (GS) } \\
\hline 2007 & $2.31 \mathrm{a}$ & $0.67 \mathrm{a}$ & $4.74 \mathrm{~b}$ & $64.16 \mathrm{a}$ & $0.59 \mathrm{a}$ & 670 & $3.86 \mathrm{a}$ & 2.04 \\
\hline 2008 & $1.74 \mathrm{~b}$ & $0.60 \mathrm{~b}$ & 7.46 a & $49.45 \mathrm{~b}$ & $0.51 \mathrm{~b}$ & 485 & $4.09 \mathrm{~b}$ & 1.98 \\
\hline LSD & 0.10 & 0.03 & 1.45 & 2.24 & 0.06 & - & 0.20 & 0.10 \\
\hline \multicolumn{9}{|l|}{ Irrigation strategy (IS) } \\
\hline D70 & $1.64 \mathrm{c}$ & $0.62 \mathrm{bc}$ & $5.17 \mathrm{~b}$ & 59.33 & 0.51 & 349 & $4.68 \mathrm{ab}$ & $2.00 \mathrm{~b}$ \\
\hline D80 & $2.13 \mathrm{~b}$ & $0.67 \mathrm{a}$ & $5.26 \mathrm{~b}$ & 57.05 & 0.54 & 440 & $4.86 \mathrm{a}$ & $2.34 \mathrm{a}$ \\
\hline D90 & $2.58 \mathrm{a}$ & $0.65 \mathrm{ab}$ & $4.07 \mathrm{~b}$ & 55.35 & 0.55 & 607 & $4.47 \mathrm{~b}$ & $2.44 \mathrm{a}$ \\
\hline $\mathrm{FI}$ & $1.75 \mathrm{c}$ & $0.59 \mathrm{c}$ & $9.89 \mathrm{a}$ & 55.49 & 0.61 & 914 & $1.89 \mathrm{c}$ & $1.25 \mathrm{c}$ \\
\hline LSD & 0.14 & 0.04 & 2.05 & 3.17 & 0.08 & - & 0.28 & 0.14 \\
\hline \multicolumn{9}{|l|}{ GS * IS } \\
\hline $2007 * \mathrm{D} 70$ & 1.89 & 0.64 & 4.19 & 67.94 & 0.52 & 384 & 4.92 & 2.14 \\
\hline $2007 * D 80$ & 2.40 & 0.68 & 4.40 & 64.95 & 0.59 & 504 & 4.77 & 2.40 \\
\hline $2007 * \mathrm{D} 90$ & 2.80 & 0.71 & 3.44 & 62.93 & 0.59 & 763 & 3.68 & 2.22 \\
\hline $2007 * \mathrm{FI}$ & 2.14 & 0.65 & 6.93 & 60.82 & 0.66 & 1027 & 2.09 & 1.40 \\
\hline $2008 * \mathrm{D} 70$ & 1.40 & 0.61 & 6.16 & 50.71 & 0.50 & 313 & 4.45 & 1.86 \\
\hline $2008 * D 80$ & 1.86 & 0.65 & 6.12 & 49.14 & 0.49 & 375 & 4.96 & 2.29 \\
\hline $2008 * D 90$ & 2.37 & 0.60 & 4.69 & 47.77 & 0.51 & 450 & 5.26 & 2.67 \\
\hline $2008 * \mathrm{FI}$ & 1.36 & 0.53 & 12.86 & 50.16 & 0.56 & 800 & 1.70 & 1.10 \\
\hline LSD & 0.20 & 0.05 & 2.90 & 4.48 & 0.17 & - & 0.40 & 0.20 \\
\hline
\end{tabular}

ANOVA

Parameters (f.d.) $\%$ Total sum of the squares

\begin{tabular}{|c|c|c|c|c|c|c|c|c|c|c|c|c|c|c|}
\hline GS (1) & 33.80 & $* *$ & 34.90 & $* *$ & 17.30 & $* *$ & 82.90 & $* *$ & 18.30 & $*$ & - & 0.80 & $*$ & $0.40 \mathrm{~ns}$ \\
\hline IS (3) & 58.00 & $* *$ & 24.30 & *** & 46.90 & $* *$ & 3.90 & ns & 17.70 & ns & - & 86.00 & $* *$ & 85.20 \\
\hline GSxIS (3) & 1.90 & ns & 13.60 & $*$ & 8.20 & ns & 2.30 & ns & 2.20 & $\mathrm{~ns}$ & - & 9.90 & $* *$ & 8.90 \\
\hline Error (24) & 6.30 & & 27.20 & & 27.60 & & 10.80 & & 61.80 & & - & 3.30 & & 5.60 \\
\hline Standard deviation & 0.14 & & 0.04 & & 1.99 & & 3.07 & & 0.12 & & - & 0.28 & & 0.14 \\
\hline
\end{tabular}

All weight values are based on fresh weight.

The drip irrigation strategy designated D70, D80, and D90 consisted in starting each irrigation event when the VSWC at $0.10 \mathrm{~m}$ depth rose to $70 \%, 80 \%$, and $90 \%$ field capacity, respectively; FI refers to furrow irrigation.

Mean values followed by different lower-case letters in each column indicate significant differences at $P \leq 0.05$ using the LSD test.

ns: no significant difference. * (**): Indicates significant differences at $P \leq 0.05(P \leq 0.01)$. 


\section{Figure captions}

Fig. 1 Monthly precipitation (P in $\mathrm{mm}$ ), reference evapotranspiration (ETo in $\mathrm{mm}$ ), and average temperature ( $\mathrm{T}$ in ${ }^{\circ} \mathrm{C}$ ) from January 2007 to January 2009.

Fig. 2 Volumetric soil water content (VSWC) throughout the growth period in 2007 and 2008. VSWC $(0.10,0.20$ and $0.30 \mathrm{~m}$ depth) corresponding to D70, D80, and D90 drip irrigation strategies and VSWC in furrow irrigation $(0.10 \mathrm{~m}$ depth) and water input for each rainfall event. The irrigation strategies designated D70, D80, and D90 consisted in starting each irrigation event when the VSWC at a $0.10 \mathrm{~m}$ depth rose to $70 \%, 80 \%$, and $90 \%$ of field capacity, respectively.

Fig. 3 Biomass accumulation of whole plants (a), leaves (b), and tubers (c), and harvest index (d), throughout the growth period in 2007 and 2008, corresponding to D70, D80, and D90 drip irrigation and furrow irrigation (FI). The irrigation strategy designated D70, D80, and D90 consisted in starting each irrigation event when the VSWC at a $0.10 \mathrm{~m}$ depth rose to $70 \%, 80 \%$, and $90 \%$ of field capacity. Vertical bars represent $\pm \mathrm{SE}$; their absence indicates that the bar size was less than that of the symbol used.

Fig. 4 Biomass accumulation $\left(\mathrm{g} \mathrm{DW} \mathrm{m}^{-2}\right.$ ) and partitioning in whole plants, leaves, roots, or tubers of nutsedge in 2007 and 2008, corresponding to the D90 drip irrigation strategy. Vertical bars represent \pm SE; their absence indicates that the bar size was less than that of the symbol used.

Fig. 5 Relationship between yield $\left(\mathrm{kg} \mathrm{m}^{-2}\right)$ and irrigation water applied ( $I_{\text {applied }}$ in $\left.\mathrm{mm}\right)$ for 2007, 2008 and for both years together. Relationship between irrigation water use efficiency (IWUE in $\mathrm{kg} \mathrm{m}^{-3}$ ) and $I_{\text {applied }}$ for 2007, 2008 and for both years together. 